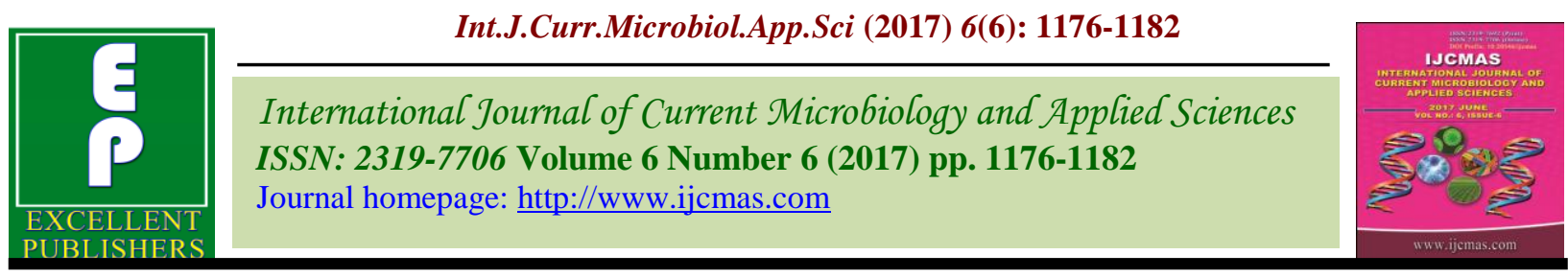

Original Research Article

https://doi.org/10.20546/ijcmas.2017.606.136

\title{
Biological Control of Root Knot Disease of Tomato caused by Meloidogyne javanica using Pseudomonas fluorescens Bacteria
}

Fakhreldin Musa Eltom Eltayeb*

Landscaping \& irrigation department, Royal commission for Yanbu,

King Abdul Aziz Street, Saudi Arabia

*Corresponding author

\section{A B S T R A C T}

Root-knot nematodes (Meloidogyne spp.) are important pests of many

Keywords

Bio-control,

Pseudomonas

bacteria, $M$.

javanica.

Article Info

Accepted:

17 May 2017

Available Online:

10 June 2017 cultivated plants. Recently the most efficient chemical control products of nematodes, (e.g. methyl bromide); have been restricted due to their toxic characteristics. This study was conducted in the area of tomatoes (Lycopersicun esculentum Mill), which have been grown commercially, in order to isolate Pseudomonas fluorescens bacteria from the soil to be used in biological control of root knot disease which caused by nematode Meloidogyne javanica, this to eliminate the use of agrochemical and their hazard on human health and environment. The results showed that the application of Pseudomonas fluorescens bacteria reduced Meloidogyne javanica galls information and number of juveniles in the soil either as a seed treatment, root dipping or as a soil drench application but seeds treatment showed a little better result than the other application methods.

\section{Introduction}

Root knot nematodes (Meloidogyne spp), are worldwide in their distribution, attack a wide variety of crops, and more than 3000 host species. The four common root-knot nematode species, namely Meloidogyne incognita, $M$. javanica, $M$. arenaria and $M$. hapla are the most abundant and damaging nematode of vegetables (Maqbool and Shahina, 2001). Various species of Meloidogyne induce major morphological and physiological changes within roots, not only yield is greatly affected but quality is also reduced (Khan et al., 2005). Control of plant parasitic nematodes is difficult because of the enormous variety of suitable hosts. Plant parasitic nematodes, are small microscopic roundworms that live in the soil and attack the roots of plants. Crop production problems induced by nematodes, therefore, generally occur because of root dysfunction, reducing rooting volume, and foraging and utilization efficiency of water and nutrients. In many cases, a mixed community of plant parasitic nematodes is present in a Field, rather than having a single species occurring alone. In addition to the direct crop damage caused by nematodes, many of these species have also been shown to predispose plants to infection 
by fungal or bacterial pathogens or to transmit virus diseases, which contribute to additional yield reductions (Noling, 2012).

Plant parasitic nematodes living belowground are difficult to control by chemical means because of large quantities and repeated applications required to treat the entire soil volume occupied by plant roots. A number of antagonistic bacteria have been reported in suppressing soil-borne pathogens and enhancing plant growth. An advantage of targeted introduction of antagonists to the plant is that microbial populations can grow from a small quantity of inoculums and colonize the rhizosphere and root (Sikora, 1992).

The most extensively studied Pseudomonas fluorescens bacteria which have been reported as a bio-control agents to reduce fungal diseases (Yang et al., 2011), bacterial diseases (Sarr et al., 2010) and plant parasitic nematodes (Munif et al., 2000; Vetrivelkalai et al., 2010). The low level of control consistency of many biocontrol agents against soil-borne pathogens under field conditions is most likely due to the complexity and variability of the soil physics, chemistry and microbial activity in the soil as well as due to environmental factors (Weller, 1988). The objectives of the present studies were to study the effect of Pseudomonas fluorescens bacteria on nematode population in the soil and gall formation of M. javanica and their effects on the plant growth.

\section{Materials and Methods}

\section{Collection of root Samples and survey}

A total number of two sites were survey. From which fifteen samples of tomatoes infected with root knot nematodes (7 to 8) samples from each site, were collected rely on above ground symptoms.

\section{Sampling from tomato plants}

Sampling from tomato plants done by uprooting the whole plant from soil using spade. Effort made to remove the entire root system by digging carefully around the roots. After excising the aerial portion, and removing soil from the root system of the uprooted plants, the roots placed in bags. All The bags tied, and labeled. One hundred grams of soil and roots from each sample processed for the isolation of nematodes. Nematodes extracted by the use of Whitehead and Hemming tray methods (Whitehead, 1986). In this method, the infested roots with egg masses washed thoroughly under tap water. The roots along with soil were kept in the tray lined with tissue paper having sufficient water that roots and soil should dipped in water and after 24 hours, the water was poured off in a beaker,and allowed to settle for one hour. When the juveniles had settled, the excess of water siphoned off until about $100 \mathrm{ml}$ remained. The suspensions of juveniles (J-2s) taken with a pipette and three replicates of 2 $\mathrm{ml}$ of aliquots of $\mathrm{J}-2 \mathrm{~s}$ were counted in a counting dish.

\section{Identification of root knot nematode based on perineal pattern}

Galls with mature females selected and placed in a Petri-dish with tap water; root tissues torn apart with forceps and half spear to remove adult females. Necks of females were cut-off with the help of a half spear to remove the interiors. The cuticle then placed in to a drop of $45 \%$ lactic acid on a plastic Petri dish. Similarly, 5-10 cuticles collected in the drop and allowed them to stand for 30 minutes. The Cuticle cut in half (equatorially) with the help of modified common blade and a portion of cuticle with perineal pattern to square shape. The trimmed perineal pattern placed back in the $45 \%$ lactic acid and cleaned free from debris, using the pulp canal file. After cleaning, the perennial pattern was transferred 
to a drop of glycerin on a clean micro slide and aligned in such a way that anus was oriented downward. A warm cover slip placed on the glycerin drop sealed with nail polish and labeled.

\section{Mass culturing of root-knot nematodes}

To multiply the culture of root-knot nematodes, the most susceptible variety of Tomatoes used. Three weeks old seedlings transplanted in pots containing $2.5 \mathrm{~kg}, 1: 2$ sandy: loam soil, sterilized with hot steam of water, one plant/pot. One week after transplanting, these plants were inoculated freshly hatched second stage juveniles of Meloidogyne javanica. Tap water used to irrigate young seedlings throughout out the period of study. The temperature range 20-30 ${ }^{\circ} \mathrm{C}$ recorded. All above steeps concern nematodes done in ministry of Agriculture research center Saudi Arabia.

\section{Re-culture of isolates of bacteria provided}

The isolate of bacteria, provided by King Fahd University microbiology laboratory where isolated,purified and identified. All these isolates of bacteria re-cultured in Royal Commission laboratory. By suspend $28 \mathrm{~g}$ powder of nutrient agar in one litter distilled water and bring to the boil to dissolve completely. Sterilized by autoclaving at 1210c for 15 minutes. After the liquid cool poured in Petri dishes, and sterilized under UV light for 10 minutes. Bacteria striped on the solid agar-using loop. The dishes covered by cellophane. Moreover, incubated in $37 \mathrm{oc}$ for 48 hours until colony development observed. Five days later bacteria used in experiments.

\section{Seeds treatment method of bacteria application experiment}

The bacteria were pre-cultured on nutrient agar medium, after 48 hours bacteria germinated. Five loops of bacteria suspended in sterilized distilled water. The tomatoes seeds were soaked in the bacterial suspension for 3 minutes using 1\% gum Arabic as a sticking agent, and then seeded into pots containing a sterilized sand/loam mixture $(1: 2, v / v)$. Each pot received three seeds. Two weeks, after seeds germination plants thinned to one plant per pot. After 2 weeks, the plants were inoculated suspended juveniles of $\mathrm{M}$. javanica. The inoculation of nematodes was carried out by drenching $5 \mathrm{ml}$ inoculums volume with the juveniles (2000 juveniles), into the soil around the roots. Seed sterile with $1 \%$ without $\mathrm{Ca}$ (ocl) 2 without bacteria served as control. Each treatment replicated 3 times. The experiment terminated 6 weeks after nematode inoculation. Tomato plant roots were wash free of adhering soil particles using tap water. The following measuring made for both treated and control.

Fresh shoots and roots weight

The numbers of galls of M. javanica recorded,

Plant height measured

Nematodes population in the soil

Isolation of nematodes from $25 \mathrm{grams}$ of treated and control soil and make account of nematodes

\section{Root dipping method of bacteria application experiment}

Roots of three-week-old tomato plants dipped for $3 \mathrm{~min}$ into the bacterial suspension and then planted into pots containing a sterilized soil (sand /loam) mixture (1:2, v/v). After 2 weeks, the plants were inoculated with $5 \mathrm{ml}$ (2000 juveniles) of M. javanica per pot. Roots without bacteria served as control used. Each treatment replicated 3 times and terminated. 6 weeks after nematode inoculation. The same 
measurings made for both treated and control were recorded.

\section{Soil drench method of bacteria application experiment}

Five $\mathrm{ml}$ bacterial suspensions pipette onto the soil surface around 3 week old tomato plants. Plants inoculated with 2000 juveniles of M. javanica 14 days after bacterial application.

The inoculation of nematodes carried out by drenching $5 \mathrm{ml}$ inoculums volume with the juveniles into the potted soil around the roots. Soil without bacteria served as control used. Plants harvested after 6 weeks after nematode inoculation. The same previous measuring made for both treated and control.

\section{Results and Discussion}

In this study bacteria Pseudomonas fluorescens, test against the nematode Meloidogyne javanica showed greatest increase in plant height which reach $48.77 \%$ over control when Pseudomonas fluorescens added as soil drench (Table 2). This may be Because of Phosphate solubilization, acetic acid, and protease enzyme produced by Pseudomonas spp, (Debora et al., 2007), moreover of bacteria population increasing in the soil. This agreed with Kloepper Schroth (1978) and Nasima et al., (2002).

The study revealed that the fresh weight of shoot showed greatest increase which increased by $173.5 \%$ over control when Pseudomonas fluorescens applied as seeds treatment (Table 1). This is due to good property of acetic acid production by Pseudomonas fluorescens. Also Proteases have potential role to reduce nematode effect on plant. The dry weight of shoot increased by $46.9 \%$ when bacteria applied as seeds treatment (Table 1). The study indicated that the treatment with Pseudomonas fluorescens decreased fresh weight of root by $56.75 \%$ when applied as soil drench (Table 2). And dry weight of root by 72.96 when applied as seeds treatment (Table 1), because of less galls information (Kloepper et al., 1999).

Effects of Pseudomonas on Nematodes population in soil showed significant results decreased by $40 \%$ under control when added as seeds treatment (Table 1).

Pseudomonas fluorescens showed more reduction in Nematodes population which means it has more effects on nematodes control effects of Pseudomonas fluorescens on galls formation revealed reduction of galls on plant roots by $78.95 \%$ under control when Pseudomonas fluorescens applied as roots dipping, which showed highly significant results regarding root knot disease control by reducing number of juveniles in soil and reduced the gall numbers on the roots. This result agreed with Javed Asghar Tariq (2008) (Table 3). The findings of this study confirmed that Pseudomonas fluorescens can be used as bio-agent to control root knot disease of tomatoes and thus reduce dependence on the synthetic nematocides and their hazards. This agrees with Kloepper, et al., (1991), Kloepper et al., (1999), Siddiqui et al., (2001), Ali et al., (2002), Li et al., (2002), Siddiqui, and Shaukat (2002), and Munif et al., (2000). The result of using bacteria in biological control of plant parasitic nematodes, agreed with Athman SY (2006) that studied the role of endophytes in biological control of plant parasitic nematodes with special reference to the banana nematode Radopholus imilis. The result of using Pseudomonas fluorescens bacteria as root dipping to control disease of tomatoes agreed with, Mulya, Watanabe, Goto, Takikawa, Tsuyumu (2006) which revealed Suppression of bacterial wilt disease in tomato by root dipping with Pseudomonas fluorescens, due to antibiotic substances and siderophore production. 
Table.1 Effect of Pseudomonas fluorescens bacteria on plant growth and on Meloidogyne javanica control when applied to tomato as seeds treatment

\begin{tabular}{|r|c|c|c|c|c|c|c|}
\hline Treatment & $\begin{array}{c}\text { Plant height } \\
(\mathrm{cm}) \% \\
\text { Increased } \\
\text { /decreased }\end{array}$ & $\begin{array}{c}\text { Fresh weight } \\
\text { of shoot(g) } \\
\text { \%Increased } \\
\text { /decreased }\end{array}$ & $\begin{array}{c}\text { Fresh weight } \\
\text { of root(g) } \\
\text { \%Increased } \\
\text { /decreased }\end{array}$ & $\begin{array}{c}\text { Dry Weight } \\
\text { of shoot(g) } \\
\text { \%Increased } \\
\text { /decreased }\end{array}$ & $\begin{array}{c}\text { Dry weight } \\
\text { of root(g) } \\
\text { \%Increased } \\
\text { /decreased }\end{array}$ & $\begin{array}{c}\text { No. of } \\
\text { Juveniles } \\
\text { /250 gram } \\
\text { of soil }\end{array}$ & $\begin{array}{c}\text { Galls No } \\
\% \\
\text { Increased } \\
\text { Decreased }\end{array}$ \\
\hline $\begin{array}{r}\text { Pseudomonas } \\
\text { fluorescens } \\
\text { +Nematode }\end{array}$ & $\begin{array}{c}\mathbf{4 3 . 8 1 \%} \\
\text { Increased } \\
\text { Decreased }\end{array}$ & $\begin{array}{c}\mathbf{1 7 3 . 5 \%} \\
\text { increased }\end{array}$ & $\begin{array}{c}\mathbf{4 5 . 9 5 \%} \\
\text { decreased }\end{array}$ & $\begin{array}{c}\mathbf{4 6 . 9 \%} \\
\text { increased }\end{array}$ & $\begin{array}{c}\mathbf{7 2 . 9 6 \%} \\
\text { decreased }\end{array}$ & $\begin{array}{l}\mathbf{4 0 \%} \\
\text { decreased }\end{array}$ & $\begin{array}{l}\mathbf{7 1 . 1 9 \%} \\
\text { Decreased }\end{array}$ \\
\hline $\begin{array}{r}\text { Nematode } \\
\text { alone }\end{array}$ & 40.33 & 17.67 & 37 & 10.66 & 23.3 & 500 & 499 \\
\hline
\end{tabular}

Table.2 Effect of Pseudomonas fluorescens bacteria on plant growth and Meloidogyne javanica control when applied to tomato soil drench

\begin{tabular}{|l|l|l|l|l|l|c|c|}
\hline Treatment & $\begin{array}{c}\text { Plant height } \\
(\mathrm{cm}) \% \\
\text { Increased } \\
/ \text { decreased }\end{array}$ & $\begin{array}{l}\text { Fresh weight } \\
\text { of shoot(g) } \\
\% \text { Increased } \\
/ \text { decreased }\end{array}$ & $\begin{array}{c}\text { Fresh weight } \\
\text { Of root(g) } \\
\% \text { Increased } \\
/ \text { decreased }\end{array}$ & $\begin{array}{c}\text { Dry Weight } \\
\text { Of shoot(g) } \\
\% \\
\text { Increased } \\
/ \text { decreased }\end{array}$ & $\begin{array}{c}\text { Dry weight } \\
\text { Of root(g) } \\
\% \\
\text { Increased } \\
/ \text { decreased }\end{array}$ & $\begin{array}{c}\text { No. of } \\
\text { Juveniles } \\
\text { /250 gram } \\
\text { Of soil }\end{array}$ & $\begin{array}{c}\text { Galls No } \\
\% \\
\text { Increased } \\
\text { Decreased }\end{array}$ \\
\hline $\begin{array}{c}\text { Pseudomonas } \\
\text { fluorsccens } \\
+ \text { Nematode }\end{array}$ & $\begin{array}{l}\mathbf{4 8 . 7 7 \%} \\
\text { Increased }\end{array}$ & $\begin{array}{l}56.59 \% \\
\text { increased }\end{array}$ & $\begin{array}{l}56.75 \% \\
\text { Decreased }\end{array}$ & $\begin{array}{l}6.29 \% \\
\text { increased }\end{array}$ & $\begin{array}{l}71.67 \% \\
\text { decreased }\end{array}$ & $\begin{array}{l}38.2 \% \\
\text { decreased }\end{array}$ & $\begin{array}{l}77.9 \% \\
\text { Decreased }\end{array}$ \\
\hline $\begin{array}{l}\text { Nematode } \\
\text { alone }\end{array}$ & 40.33 & 17.67 & 37 & 10.66 & 23.3 & 500 & 499 \\
\hline
\end{tabular}

Table.3 Effect of Pseudomonas fluorescens bacteria on plant growth and Meloidogyne javanica control when applied to tomato roots dipping

\begin{tabular}{|l|l|l|l|l|l|c|c|}
\hline Treatment & $\begin{array}{c}\text { Plant height } \\
(\mathrm{cm}) \% \\
\text { Increased } \\
/ \text { decreased }\end{array}$ & $\begin{array}{c}\text { Fresh } \\
\text { weight of } \\
\text { shoot(g) } \\
\% \text { Increased } \\
/ \text { decreased }\end{array}$ & $\begin{array}{c}\text { Fresh } \\
\text { weight } \\
\text { of root(g) } \\
\text { \%Increased } \\
\text { /decreased }\end{array}$ & $\begin{array}{c}\text { Dry Weight } \\
\text { of shoot(g) } \\
\text { \%Increased } \\
/ \text { decreased }\end{array}$ & $\begin{array}{c}\text { Dry weight } \\
\text { of root(g) } \\
\text { \%Increased } \\
\text { /decreased }\end{array}$ & $\begin{array}{c}\text { No. of } \\
\text { Juveniles } \\
\text { /250 gram } \\
\text { of soil }\end{array}$ & $\begin{array}{c}\text { Galls No } \\
\% \\
\text { Increased } \\
\text { Decreased }\end{array}$ \\
\hline $\begin{array}{l}\text { Pseudomonas } \\
\text { fluorsccens } \\
+ \text { Nematode }\end{array}$ & $\begin{array}{l}43.81 \% \\
\text { Increased }\end{array}$ & $\begin{array}{l}124.5 \% \\
\text { increased }\end{array}$ & $\begin{array}{l}33.32 \% \\
\text { decreased }\end{array}$ & $\begin{array}{l}31.32 \% \\
\text { increased }\end{array}$ & $\begin{array}{c}71.67 \% \\
\text { decreased }\end{array}$ & $\begin{array}{l}39 \% \\
\text { decreased }\end{array}$ & $\begin{array}{l}78.95 \% \\
\text { Decreased }\end{array}$ \\
\hline $\begin{array}{l}\text { Nematode } \\
\text { alone }\end{array}$ & 40.33 & 17.67 & 37 & 10.66 & 23.3 & 500 & 499 \\
\hline
\end{tabular}

The result of using bacteria as bio-agent to control tomatoes disease agreed with Arika Purnawatil, Ika Rochdjatun Sastrahidayat, Abdul Latief Abadi Tutung Hadiastono (2014) the research confirmed using Pseudomonas fluorescens bacteria as biocontrol agents of tomato bacterial wilt disease. This study agreed with Pakistan Journal of Agriculture, Agricultural Engineering and Veterinary Sciences (2011) who concluded from his studies that Pseudomonas fluorescens used against 
Meloidogyne javanica, showed juvenile mortality.

The results of the present study supported by the study of Munif, Hallmann and R.A. Sikora (2000) which concluded that Pseudomonas. Is able to reduce the number of penetrating nematodes and root galls of tomato when applied as a root dipping, soil drench and Seed treatment.

Present study agreed with Samaraj Subramanian Thiyagarajan (2014) study which concluded that Pseudomonas fluorescens nematode resistance was compared with chemical and untreated plants. In summary, the study concludes that Pseudomonas fluorescens comparatively was more effective in sustained control of nematodes.

This result agreed with Javed Asghar Tariq, (2008). Who concluded from his studies that Pseudomonas fluorescens used against Meloidogyne javanica to control root knot disease of tomatoes?

All the previous studies agreed with present study in using bacteria as bio-agent to control root knot diseased of tomato caused by plant parasitic nematode as well as other disease of tomatoes. Pseudomonas fluorescens bacteria is able to control root Knot disease on Tomato caused by Meloidogyne javanica nematode, by reduction of galls number on the roots and nematode population in soil. When applied as a root dipping, soil drench and seed treatment. Pseudomonas fluorescens bacteria can uses as bio- agent to control Nematode.

\section{Acknowledgements}

Thanks to Faculty of Agriculture and Microbiology laboratory of king Saud University for their helps thanks to royal commission research center, thanks to D. Mountasir Adam for this guidance.

\section{References}

Hallmann, J., Quadt-Hallmann, A., Rodriquez-Kabana, R. and J.W. Kloepper. 1998. Interaction between Meloidogyne incognita and endophytic bacteria in cotton in relation to nematode control. Soil Biol. Biochem., 30(7): 925-937.

Hallmann, J., Quadt-Hallmann, A., Mahaffee, W.F. and J.W. Kloepper. 1997. Bacterial endophytes in agricultural crops. Can. J. Microbial., 43: 895-914.

Khan, H.U., T. Mukhtar, and R. Ahmed. 2005. Geographical distribution of root knot.

Kloepper, J.W., Leong, J., Teintze, M., Schroth, M.N. 1980. Enhanced plant growth by siderophores produced by plant growth-promoting rhizobacteria. Nature, 286: 885-886

Kloepper, J.W., Schroth, M.N. 2005. Plant growth promoting rhizobacteria on radishes. In Station de pathology vegetable etphyto-bacteriologie (ed.), Proceedings of the 4th International Conference on Plant Pathogenic Bacteria, vol. II. Gilbert- Clarey, Tours, France, Pp. 879-882.

Noling, J.W. 2013. Nematode Management in Cucurbits (Cucumber, Melons, Squash).

Noling, J.W. 2012. ENY-032, one of a series of the Entomology and Nematology Department, Florida Cooperative Extension Service, Institute of Food and Agricultural Sciences, University of Florida.

Sarr, P.S., Yamakawa T., Asatsuma S., Fujimoto S. and M. Sakai. 2010. Investigation of endophytic and symbiotic features of Rasltonia sp. TSC1 isolated from cowpea nodules. Afr. J. Microbiol. Res., 4: 1959-1963.

Sikora, R.A. 1992. Management of the antagonistic potential in agricultural ecosystems for the biological control of 
plant-parasitic nematodes. Ann. Rev. Phytopathol., 30: 245-270.

Sikora, R.A. 1992. Management of the antagonistic potential in agricultural ecosystem for the biological control of plant parasitic nematodes. Annul. Rev. Phytopathol., 30: 245-270.

Sikora, R.A., Fernández, E. 2005. Nematodes parasites of vegetables. In: Plant parasitic nematodes in subtropical and tropical agriculture. Liuc M., Sikora R.A., Bridge J. (Eds.). CAB International, Wallingford, UK. 319392

Sikora, R.A., Pocasangre, L., zum Felde, A., Niere, B., Vu, T.T., Dababat, A.A. 2008. Mutualistic endophytic fungi and in-plant suppressiveness to plant parasitic nematodes. Biol. Control, 46: $15-23$.

Sikora, R.A., Schäfer, K., Dababat, A.A. 2007. Mode of action associated with microbially induced in plant suppression of plant-parasitic nematodes. Australasian Plant Pathol., 36: 124-134.
Spiegel, Y., Cohn, E., Galper, S., Sharon, E. and I. Chet. 1991. Evaluation of e newly isolated bacterium, Pseudomonas chitin olytica for controlling the root-knot nematode Meloidogyne javanica. Biocontrol Sci. Tech., 1: 115-125.

Vetrivelkalai, P., Sivakumar M. and F.I. Jonathan. 2010. Bio-control potential of endophytic bacteria on Meloidogyne incognita and its effect on plant growth in bhendi. J. Bio-pest, 3: 52-457.

Weller, D.M. 1988. Biological control of soil borne plant pathogens in the rhizosphere with bacteria. Annual Review of Phytopathology, 26: 379 407Wesemael W.M.L., Viaene N.; Moens M. 2011. Root knot nematodes (Meloidogyne spp.) in Europe. Nematol., 13(1): 3-16.

Weller, D.M., and Cook, R.J. 1983. Suppression of take-all of wheat by seed treatments with fluorescent Pseudomonas. Phytopathol., 73: 463469.

\section{How to cite this article:}

Fakhreldin Musa Eltom Eltayeb. 2017. Biological Control of root knot disease of tomato caused by Meloidogyne javanica using Pseudomonas fluorescens bacteria. Int.J.Curr.Microbiol.App.Sci. 6(6): 1176-1182. doi: https://doi.org/10.20546/ijcmas.2017.606.136 